\title{
Strategy to Determine the Priority of Teachers' Quality Problem Using USG (Urgency, Seriousness, Growth) Matrix
}

\author{
Nova Syafira Ariyanti* \\ Maulana Amirul Adha \\ Raden Bambang Sumarsono \\ Sultoni \\ Universitas Negeri Malang \\ (corresponding author) ${ }^{*}$ \\ $\checkmark$ novasyafira2@gmail.com
}

\begin{abstract}
The purpose of this study is to know, (1) identify the problem of teachers' and educational personnel, (2) the application of USG matrix method, and (3) the impact of the problems of the educator components and education in learning at integrated islamic primary school. The method used in this study is qualitative descriptive. The research performs analysis using the matrix theory Urgency, Seriousness and Growth (USG). The site of this research is at SD Islam Terpadu Robbani Malang Regency, Indonesia. Data collection techniques with in-depth interviews, documentation, and library studies. The analysis of the data in the get resulted in the findings that correspond to the problems faced by the school. The results of the study are (1) problems that cause low PTK (Teachers and Educational Personnel) values i.e. teacher qualifications are not appropriate, teachers do not have a certificate of teachers', and teachers do not teach in accordance with educational background, (2) problems that must be resolved in advance that (a) the teachers do not teach in accordance and (b) learners are lacking in receiving learning.
\end{abstract}

Key words: quality, teachers, USG matrix, an integrated islamic primary school

\section{INTRODUCTION}

Quality is an important part as a foundation that demonstrates the excellence of a product or service (Claude Ah-Teck \& Starr, 2014; Mehta \& Degi, 2019). Every institution must have a strategy to improve the quality that it manages. In fact, improving quality also requires the role or involvement of all members in the organization (Pfeffer, 2015). Likewise with an education that is a major factor in shaping human personal. This as a way to improve the quality of an education should also be considered. As in the test results (PISA, 2018) stated that Indonesia's education ranks 72 from 77 countries in literacy, 72 from 78 in mathematics, and 70 from 78 countries in science. Based on the results of the PISA test organized by the OECD (Organisation for Economic Co-operation and Development), Indonesia has increased its ranking because there are several newly merged countries. For the improvement of quality in education organizations in 
Indonesia should also improve the quality of the school, because by improving the quality of schools directly, the quality of Indonesian education will also increase. If we see primary and secondary education impact when learners are at a higher level. Education in Indonesia is now obliged to study 12 years, so that students get the opportunity to obtain an education.

Some indicators of educational organizers to improve the quality of the establishment of the personality of students on a regular basis and grow into human beings who have character and noble character and provide basic intellectual ability such as read write and Count (Hopkins, 2015; Mincu, 2015; Tilaar, 2008). On this indicator if seen from education in Indonesia, especially at the basic level many problems encountered. One of the problems that impedes the above indicator is that it is not as qualified as the teacher's workforce with the background or background needed. If the indicator of the education to improve the quality of the achievement of the personality of the students then if the school recruits teachers who are not in the background of education, then to change the learners to better be felt difficult.

Teachers are expected to improve the quality of education in schools (Elliott, 2015). The sophistication of curriculum and school management guidelines will not mean if not handled by professional teachers, therefore the demands on teacher professionalism are reasonable. The success of teachers in the classroom is not merely the achievement of learning objectives, but the success of teachers is also determined to develop their students ' skills, because the teacher as a change agent (Adha, Sunandar, et al., 2019; Juharyanto, 2012; Kondakci et al., 2017). Based on research conducted by (Grijalva \& Enriquez-gates, 2019) That the teacher as a change agent is able to develop and improve the pattern of the think and combine three elements such as building partnerships, engaging in class action research to develop its professionalism, and implementing frameworks as managing change in learning. It should be achieved when supported by adequate human resources management in the institution of education (Makin et al., 2018). One of the techniques that can be used is the problem solving technique using matrices USG USG (Urgency, Seriousness, Growth) (Ambardi, 2014; Surendran, 2018).

\section{LITERATURE REVIEW}

USG Matrix is an abbreviation of Urgency, Seriousness, Growth. This USG matrix itself is usually used in health sciences, as the age of development can also be applied in the field of educational sciences. In setting an actual issue we can use one of the tools in the analysis technique i.e. Urgency, Seriousness, Growth (USG) matrix (Lembaga Administrasi Negara RI, 2008). Urgency is a way to see how urgent the issue is, so the need to be discussed and not to forget with the time is also taken into account. Furthermore, that is seriousness, at this stage the issue is associated with the consequences that will arise if the issue is not resolved immediately, it is necessary to understand that in the same condition or situation, an issue that can cause other problems is more serious when compared with a stand-alone problem, the next at the growth stage is likely the issue becomes worse if left (Masiani, 2017; Riswanto, 2016).

USG is one of the tools to compile the order of priority issues to be resolved (Lembaga Administrasi Negara RI, 2008). How to use this USG matrix should provide a scale of judgment at each stage or step, the 
scale given which is a range of 1-5 or 1-10. Issues or issues that have the highest total score are priority issues. This is done to facilitate researchers and readers in the USG table or matrix. An example of the USG matrix table can be seen in Table 1. Based on the example in Table 1. The problem being a priority is issue C.

Table 1. Example of Using USG matrix

\begin{tabular}{cllllc}
\hline Number & Problem & U & S & G & Total \\
\hline 1 & A Problem & 5 & 3 & 3 & 11 \\
2 & B Problem & 4 & 4 & 4 & 12 \\
3 & C Problem & 4 & 5 & 5 & 14 \\
\hline
\end{tabular}

\section{Description:}

The scale value of the extracted range is $1-5$, the scale drawn ranges from 1-5 to facilitate readers and researchers.

In human resource management, being professional is the demands of position, occupation or profession (Maring \& Koblinsky, 2013; Stronge et al., 2011). There is one important thing that is an aspect for a profession, namely professional attitude and quality of work, in the perspective of human resources development, become a professional is a unity between personality concepts and integrity that is matched with Skil or its expertise. Being a professional teacher or having expertise in educating or teaching needs adequate education, training and experience (Dar, 2018; Frank, 2015), There are several criteria for becoming a professional teacher; (1) have adequate intellectual capacity; (2) Ability to understand the vision and mission of education; (3) skill in transferring science or methodelogi learning; (4) Understanding the concept of child development/developmental psychology; (5) The ability to organize and problem solving; and (5) creative and have an art in educating (Coe et al., 2014; Korthagen, 2013; Miller, 2012). Seeing the role, it is the absolute will that the teacher must have good and true integrity and personality. It is very basic, because the task of the teacher is not just teaching (transfer knowledge) but also embed the character values in the learners.

\section{METHOD}

\section{Research Design}

The method used in this study is qualitative descriptive with a case study approach. Qualitative research is a qualitative method to explore and understand the meaning by a number of individuals or groups of people coming from social or humanitarian issues (Creswell, 2014). According (Ulfatin, 2015) Qualitative descriptive research aims to illustrate the characteristic phenomenon with narrative-related description. The qualifications research is used to respond thoroughly to the research problem. Researchers act as key instruments as well as data collectors to capture meaning and interactions. Research location is done at SD Islam Terpadu Robbani District of Malang, Province East Java, Indonesia. 


\section{Data Collection and Analysis}

Researchers collect and analyze qualitative data at the same time through four phases of data analysis as expressed (Miles et al., 2014). There are four phases of qualitative data analysis namely data collection, condensation, validation, and withdrawal conclusions. All four phases are done in the same time during the research process. Qualitative Data is mainly about the process of learning in classes conducted by teachers that are obtained through observation, interviews, documentation and literature review. Data selection is done using snowballs techniques. Key informant in this research is the principal and additional informant of the teacher. The literature study in this study uses sources such as newspapers, internet, journals, and books relevant to the issues studied. The research also uses the USG Matrix Analysis Technique (Urgency, Seriousness, Growth).

\section{Validity and Reliability}

The validity and reliability of data is confirmed by the triangulation of the source and method. In the triangulation source, data from various sources is compared to get valid data. For example, data from respondents compared to other highly related respondents like their friends to check whether they are providing the same information or not. When the information is identical, the data can be summed up valid and reliable. In the triangulation method, data from various methods such as observation, interviews, and documentation compared to get more valid data. For example, data from observations is confirmed by interviews with the respondents involved. Their statements are also compared to relevant documents such as school Accresitation reports. When information from different methods has identical attributes, the data is summed up to be valid and reliable. As well as in checking the validity of data, researchers increase diligence, and pay attention to reference adequacy.

\section{RESULT AND DISCUSSION}

\section{Application of USG Matrix Method}

The problem is in the recruitment of teachers. Human resources such as teachers are the most important factors in the education system (McEwan, 2015; Shahmohammadi, 2017). The quality of the school is determined by some of the components in it, from the quality of the school will have an impact on the society's Animo to school their children. Therefore, it is necessary to solution to the low quality problem of this school through teacher recruitment system at SD Islam Terpadu Robbani.

Regardless of the problem to improve the quality of the school, there is also a problem in human resources or HR, where the problem can be seen based on the results of accreditation on the components of teachers and educational personnel (PTK). Among other components that get the lowest value is PTK. So, in this case need to be done analysis of the cause why PTK in the SD Islam Terpadu Robbani got a low component. Because, human resources management is a major milestone in the school so that a system can run. Urgency, Seriousness, Growth or USG is one of the tools to compile the priority sequence of issues that must be resolved. 
A search for a problem that is important is also the steps. Here are the steps using the USG method (Khairudi, 2017; Pirdaus, 2017); (1) Preparation, when going to use this method of USG need to be prepared to divide the job description of each party in the organization, then drafted the chairman, officers to record the flipchart, scoring officers and rankings, Notulis, and to prepare the meeting room or other means. The use of meeting rooms should be in the form of $U$ letters so that the open ends can be placed chalkboard; (2) Determining the participant, in determining the participant of a leader should be able to see the ability of its members who have the ability to analyse problems; (3) Preparing the required data, the data required is the result of the analysis of the situation, the information of the resources owned, and the documents on applicable legislation and policies; (4) Group dynamics process, this step is a core step. In this step the leader role as the course of discussion is the greatest role or as a key to the passage of this method, resulting in a valid data for the problem to be resolved.

Based on the above exposure and problem analysis techniques. Here in Table 2 The problem that appears in SD Islam Terpadu Robbani to do USG analysis in order to find out which problem to be solved first. Once found the problem to be resolved first, and found the main cause.

Table 2. Issues of Educator and Education Component at SD Islam Terpadu Robbani

\begin{tabular}{clllcc}
\hline Number & \multicolumn{1}{c}{ Problem } & U & S & G & Total \\
\hline 1 & $\begin{array}{l}\text { The teacher's academic qualifications } \\
\text { still do not meet } \\
\text { Teachers do not have a certificate of } \\
\text { educators }\end{array}$ & 3 & 3 & 2 & 8 \\
3 & $\begin{array}{l}\text { Teachers do not teach in accordance with } \\
\text { educational background }\end{array}$ & 4 & 5 & 4 & 13 \\
\hline
\end{tabular}

\section{Description:}

The scale value of the extracted range is 1-5, the scale drawn ranges from 1-5 to facilitate readers and researchers.

Here's an explanation of each issue based on Table 2.

\section{(1) The teacher's academic qualifications still do not meet}

Urgency: There are 23 teachers at the SD Islam Terpadu Robbani but for academic qualified teachers, while there are 13 teachers, so they will have an impact on improving the quality of school;

Seriousness: Some of the consequences that arise on this issue that is, (a) the quality of the school decreases, (b) not too master of didactic and methodic will impact the learners;

Growth: This issue may develop, if the school's selection returns to receive prospective educators who are not qualified.

\section{(2) Teachers have no certificate of Educators}

Urgency: At the time of selection, the school receives teachers who are capable of mastering the class and not paying attention to teacher qualifications;

Seriousness: Some of the consequences that arise on this issue are, (a) teachers are not academically qualified from education, (b) school needs teachers, while applicants from non-education; 
Growth: This issue may develop, if the school's selection returns to receive prospective teachers who are not qualified.

\section{(3) Teaching teachers do not comply with the educational background}

Urgency: This issue is an issue that has already occurred, because the fault is located when the selection process of the acceptance of new educators or teachers;

Seriousness: Some of the consequences that arise on this issue are, (a) lacking in didactic and methodic mastery, (b) learners lack in receiving learning;

Growth: This issue can develop, if when the school's selection returns to receive prospective teachers who are not in accordance with the qualifications, then the quality of the school will remain low and reduce the time the teacher teaches when it should follow the the PPG or school back.

\section{The Impact of the Educator Components in Learning}

Based on the analysis of the problem using the USG method above the problem that must be resolved first that the teaching teacher does not match the background of education. The urgency of the problem got a value of 4 because, the problem arises because when the selection of the acceptance of new teachers there are no applicants set in the background of education. Schools feel the need for teachers to process learning also pretests teaching in the classroom, and the prospective teachers are able to explain.

According to the urgency it is done seriousness to find the impact on the problems that arise. The impact is (a) lacking in didactic and methodic mastery, and (b) learners lack in receiving learning. Once found the impact of the problem, further growth to see how likely it appears when the problem is associated with the consequences. The possibility that arises that the quality of the school will remain low and reduce the time teachers teach when to follow the the PPG (Program Profesi Guru).

Speaking of the quality of human resources, education plays a very important role in the process of improving the quality of human resources. Education Input is an absolute must be within certain boundaries but not a guarantee can automatically improve the quality of education (school resources are necessary but not sufficient condition to improve student achievement) (Krall, 2015). Governments must also pursue teacher improvement programs as a sustainable process. The professional improvement Program for teachers that can be done, among others (Adha, Supriyanto, et al., 2019; Hoekstra \& Korthagen, 2011; Rahmawati, 2009) (1) A standard and selective recruitment pattern; (2) Integrated, level and continuous training (long life eduction); (3) Education and standardization of Education mimimums; (4) Self-development and motivation for research; (5) Enrichment of creativity to be a teacher of work (teacher who can become teacher).

Based on exposure to previous problems, the head of SD Islam Terpadu Robbani can make efforts to increase by providing financial incentives and forming a working team of teachers to improve their competence in teaching (Burhanuddin et al., 2018; Hawkinson et al., 2017; Makin et al., 2018). The provision of financial incentives can be done by the principal by submitting a scholarship application letter for teachers who will continue the school back in accordance with its qualifications. As for forming the 
teacher's working team, the principals can be done so that the teachers who are not fit in their qualifications can share their experience with the teachers who are in the background.

\section{CONCLUSION}

Based on the above problem analysis techniques, the problem was found that caused PTK standard in SD Islam Terpadu Robbani got low value. The problem that arises (1) The teacher's academic qualification still does not meet the standards, (2) The teacher has no certificate of Educators, and (3) The teacher does not teach in accordance with the educational background. After analysis using the method of USG problems that must first be resolved IE teachers do not teach in accordance with educational background, because there are some impacts that arise. Such impacts are, (a) lacking in didactic and methodic mastery, and (b) learners lack in receiving learning.

Based on the conclusion, the advice is formulated for (1) head of the district office of Malang, should be able to formulate policies that can promote the quality improvement of teachers; (2) The head of SD Islam Terpadu Robbani, should be able to establish the operational standards of standard and selective teacher recruitment procedures; (3) Teachers in SD Islam Terpadu Robbani, should always be racing in terms of self-development and always upgrading capabilities according to the development of the era; and

(4) Other researchers, should this article be used as reference for further research in expressing other undiscovered factors regarding the concept of quality improvement of the teacher in order to achieve the success of education in school.

\section{REFERENCES}

Adha, M. A., Sunandar, A., \& Ariyanti, N. S. (2019). Analisis Prospektif Kebijakan Penghapusan Pembelajaran Calistung Pada Kelas Rendah Sekolah Dasar. Jurnal Manajemen Dan Supervisi Pendidikan, 3(3), 124-129. http://journal2.um.ac.id/index.php/jmsp/article/view/7766/4139

Adha, M. A., Supriyanto, A., \& Timan, A. (2019). Strategi Peningkatan Mutu Lulusan Madrasah Menggunakan Diagram Fishbone. Tarbawi: Jurnal Keilmuan Manajemen Pendidikan, 5(1), 11-22. http://jurnal.uinbanten.ac.id/index.php/tarbawi/article/view/1794/1579

Ambardi, R. (2014). Menentukan Prioritas Masalah Dengan Menggunakan Matrik USG. https://prezi.com/lhrav59adise/menentukan-prioritas-masalah-dengan-menggunakan-matrik-usg/

Burhanuddin, B., Supriyanto, A., \& Pramono Adi, E. (2018). Leadership Orientation as Mediator of Organizational Culture Effects on School Leadership. 3rd International Conference on Educational Management and Administration, 230-236. https://doi.org/10.2991/coema-18.2018.52

Claude Ah-Teck, J., \& Starr, K. E. (2014). Total Quality Management in Mauritian Education and Principals' Decision Making for School Improvement. Journal of Educational Administration, 52(6), 833. https://doi.org/10.1108/JEA-06-2012-0075

Coe, R., Aloisi, C., Higgins, S., \& Major, L. E. (2014). What Makes Great Teaching? The Center for Evaluation and Monitoring, October, 2-57.

Creswell, J. C. (2014). Research Design: Qualitative, Quantitative, and Mixed Methods Approaches (4th ed.). Sage.

Dar, R. A. (2018). Qualities of Effective Teachers. International Journal of Advanced Multidisciplinary Scientific Research, 1(10), 82-87. https://doi.org/10.31426/ijamsr.2018.1.10.1019

Elliott, K. (2015). Teacher Performance Appraisal : More about Performance or Development? Australian Journal of Teacher Education, 40(9), 112-116. https://doi.org/http://dx.doi.org/10.14221/ajte.2015v40n9.6

Frank, J. (2015). Building a Better Teacher. Education and Culture, 31(1), 89-95. https://doi.org/10.1353/eac.2015.0000 
Grijalva, R., \& Enriquez-gates, A. (2019). Teacher as Change Agent : Promoting Meaningful Professional Development Using Action Research to Support. FIRE: Forum for International Research in Education, 5(2), 214-225.

Hawkinson, L. E., Faria, A.-M., Bouacha, N., Lee, D. H., \& Metzger, I. (2017). Quality Improvement Efforts among Early Childhood Education Programs Participating in Iowa's Quality Rating System. In Regional Educational Laboratory Midwest. https://files.eric.ed.gov/fulltext/ED573043.pdf

Hoekstra, A., \& Korthagen, F. (2011). Teacher Learning in a Context of Educational Change: Informal Learning Versus Systematically Supported Learning. Journal of Teacher Education, 62(1), 76-92. https://doi.org/10.1177/0022487110382917

Hopkins, D. (2015). Improving the Quality of Education for All : A Handbook of Staff Development Activities (Second Edi). Routledge.

Juharyanto. (2012). Implementasi Kompetensi Kepala Sekolah Sebagai Agen Perubahan pada Sekolah Berprestasi: Studi Multi Kasus Pada Tiga SD/MI Berprestasi Di Kabupaten Bondowoso, Kabupaten Jember dan Kabupaten Situbondo. Ph.D Thesis Universitas Negeri Malang.

Khairudi, A. A. (2017). Menetapkan Urutan Prioritas Masalah. Course Hero. https://www.coursehero.com/file/p5fcbsm/b-Menetapkan-Urutan-Prioritas-Masalah-Mengingatadanya-keterbatasan-kemampuan/

Kondakci, Y., Beycioglu, K., Sincar, M., \& Ugurlu, C. T. (2017). Readiness of Teachers for Change in Schools. International Journal of Leadership in Education, 20(2), 176-197. https://doi.org/10.1080/13603124.2015.1023361

Korthagen, F. A. J. (2013). In Search Of The Essence Of a Good Teacher: Toward a More Holistic Approach In Teacher Education. Advances in Research on Teaching, 19(1), 241-273. https://doi.org/10.1108/S1479-3687(2013)0000019015

Krall, G. (2015). Necessary and Sufficient Conditions for School Improvement. NewTech Network. https://newtechnetwork.org/resources/necessary-sufficient-conditions-school-improvement/

Lembaga Administrasi Negara RI. (2008). Isu Aktual Sesuai Tema: Modul Pendidikan dan Pelatihan Kepemimpinan Tingkat III. Lembaga Administrasi Negara RI.

Makin, M., Abdullah, Z., \& Shafee, S. (2018). The Art of Supervision: Role of Supervisory Skills in Developing Teacher Capacity. Malaysian Online Journal of Educational Management, 6(4), 37-55. https://doi.org/10.22452/mojem.vol6no4.3

Maring, E. F., \& Koblinsky, S. A. (2013). Teachers' Challenges, Strategies, and Support Needs in Schools Affected by Community Violence: A Qualitative Study. Journal of School Health, 83(6), 379-388. https://doi.org/10.1111/josh.12041

Masiani, K. (2017). Peningkatan Kompetensi Staf Pengelola Perpustakaan dalam Upaya Optimalisasi Pelayanan terhadap Pemustaka. Jurnal Pari, 3(2), 99-104.

McEwan, P. J. (2015). Improving Learning in Primary Schools of Developing Countries: A Meta-Analysis of Randomized Experiments. Review of Educational Research, 85(3), 353-394. https://doi.org/10.3102/0034654314553127

Mehta, A., \& Degi, F. R. (2019). Total Quality Management Implementation, and its Barriers in Education System. International Scientifc Journals, 3(1), 36-42. https://doi.org/10.31219/osf.io/k26tq

Miles, M. B., Huberman, A. M., \& Saldana, J. (2014). Qualitative Data Analysis. Sage.

Miller, B. Y. P. (2012). Ten Characteristics of a Good Teacher. Journal English Teaching Forum, 25(1), 13.

Mincu, M. E. (2015). Teacher Quality and School Improvement: What is the Role of Research? Oxford Review of Education, 41(2), 253-269. https://doi.org/10.1080/03054985.2015.1023013

Pfeffer, F. T. (2015). Equality and Quality in Education a Comparative Study of 19 Countries. Social Science Research, 51(1), 350-368. https://doi.org/10.1016/j.ssresearch.2014.09.004

Pirdaus. (2017). Optimalisasi Pengembangan Kurikulum Berbasis Peningkatan Kompetensi Guru dalam Melaksanakan Penelitian Tindakan Kelas. Kementerian Pendidikan Dan Kebudayaan RI. http://repositori.kemdikbud.go.id/13273/1/Optimalisasoi Pengembangan Kurikulum Fasilitas....pdf

PISA. (2018). Insights and interpretations (Issue 5).

Rahmawati, T. (2009). Perbaikan Mutu Tenaga Pendidik di Sekolah sebagai Proses Berkelanjutan. Jurnal Manajemen Pendidikan, 1-10. http://staffnew.uny.ac.id/upload/132304797/penelitian/Perbaikan+mutu+tenaga+pendidik+berkelanjuta n.pdf 
Riswanto, A. (2016). Kemiskinan: Faktor Penyebab dan Analisis Pemecahan Masalah Poverty: Causes and Troubleshooting Analysis. Jurnal Sosial Humaniora, 7(1), 59-72.

Shahmohammadi, N. (2017). The Evaluation of Teachers' Job Performance Based on Total Quality Management (TQM). International Education Studies, 10(4), 58-64. https://doi.org/10.5539/ies.v10n4p58

Stronge, J. H., Ward, T. J., \& Grant, L. W. (2011). What Makes Good Teachers Good?: A cross-case analysis of the connection between teacher effectiveness and student achievement. Journal of Teacher Education, 62(4), 339-355. https://doi.org/10.1177/0022487111404241

Surendran, S. (2018). Application of Total Quality Management in Education - An Analysis. IOSR Journal of Business and Management, 20(5), 80-85. https://doi.org/10.1108/09513549610146114

Tilaar, H. A. R. (2008). Manajemen Pendidikan Nasional : Kajian Pendidikan Masa Depan. Remaja Rosdakarya.

Ulfatin, N. (2015). Metode Penelitian Kualitatif di Bidang Pendidikan: Teori dan Aplikasinya. Media Nusa Creative. 